\title{
Document Identifier Type Code
}

National Cancer Institute

\section{Source}

National Cancer Institute. Document Identifier Type Code. NCI Thesaurus. Code 693811.

A coded value specifying the kind of document identifier. 